\title{
JUURNAL_RU
}

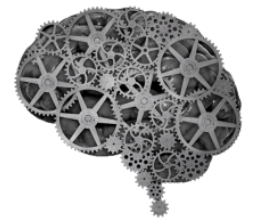

COMPANY GROUP "INTELLEKT"

Каркаева М.А. Кабардино-Балкарский государственный университет Нальчик, Россия

doi: 10.18411/1j2016-5-2-12

\section{Slanguage или универсальный язык молодежи}

Сленг, являясь одним из нестандартных вариантов языка или говоря иначе субстандартом, представляет собой наиболее динамический пласт лексикосемантической системы общенационального языка. Исследование этого экспрессивного, разнообразного, альтернативного словаря вызывает интерес многих отечественных и зарубежных лингвистов на протяжении долгого времени. Новым этапом в его изучении стало более тщательное изучение его категорий, одной из которых является социолект молодежи.

Господствующий пафос молодежной субкультуры основывается на стремлении к самовыражению и протесте против правил и авторитетов, проявляющемуся в неординарном, порою шокирующем поведении, в том числе и языковом. По этой причине молодежный сленг отмечен не просто новыми, небывалыми прежде лексическими единицами, нередко сильно сниженными стилистически. В нем присутствуют слова, внутренняя форма которых не просто не мотивирована, а парадоксальна, причём их количество в молодежном жаргоне особенно велико [1].

Сленг относится к неформальной лексике, представленной рядом синонимов тех слов и фраз, которые используются в общепринятом языке. Как правило, его ассоциируют с необразованными, маргинальными людьми или группами людей. Однако в наши дни сленг охватывает все социальные группы, субкультуры и виды деятельности. Он активно меняется с течением времени, 
согласно моде и предпосылкам его пользователей. Некоторые сленговые слова могут стать настолько обыденными, нейтральными в использовании, что со временем начинают соответствовать стандарту языка. Другие используются в течение короткого времени и быстро исчезают из употребления. Почему они исчезают? Этому может способствовать целый ряд причин. Сленг - это всегда то, что отвечает моде, это самый активно обновляющийся пласт лексики. Он обновляется, в ответ на изменения в обществе. Как только проходит популярность того или иного явления, слово, его обозначающее, заменяется чем-то иным. Некоторые сленговые слова обязаны своим появлением реальной политической ситуации или известной личности, относящейся к этой эпохе. После того как эти события теряют свою актуальность или люди теряют свою яркость, отдельные жаргонные слова, связанные с ними, исчезают также быстро как они были созданы. Большинство сленговых слов, используемых современными подростками, в основном связано с новыми технологиями. И также быстро как развиваются инновационные технологии, развивается и язык молодежи. Например, предшествующие поколения начали пользоваться интернетом и мобильными телефонами относительно недавно, поэтому они могут и не знать таких слов, как: погуглить (что-либо искать в интернете), зафейсбукить (кого-либо добавить на фейсбук) или таких аббревиатур как лол и имхо. Таким образом, сеть Интернет - это один из важнейших инструментов быстрого распространения сленга.

Сленг максимально разнообразен. Это социолект, который имеет свои отличия в каждом регионе в пределах одной страны. Даже каждый отдельный район более или менее крупного города может иметь свои специфические сленговые выражения, непонятные жителям другого. Особенности социолекта не ограничиваются рамками одной страны. В условиях всеобщей глобализации и общедоступности информации многие основные сленговые слова и выражения идентичны во многих странах и образуют интернациональный сленг. Молодые люди во всем мире смотрят одинаковые сериалы, слушают одну и ту же музыку, 
являются пользователями одних и тех же социальных сетей, поэтому неудивительно, что они начинают активно употреблять одни и те же субстандартные лексические единицы, существующие в форме заимствования, чаще всего из английского языка. Такие слова как cool, ok, hi, селфи, лайк, репост - знает почти каждый подросток. Таким образом, молодежный сленг выступает и как инструмент глобализации.

Каждое общество состоит из различных субкультур. Представители различных социальных слоев могут стать их членами в соответствии со своими интересами и идеями. Каждая субкультура влияет на речь, которая опирается на определенный лексикон. Этот словарь становится одной из главных отличительных особенностей этого сообщества. Члены этих субкультур имеют собственный сленг и используют его, чтобы доказать что разделяют одни и те же идеи и принадлежат к одной группе. Быть частью группы - это основная причина использования сленга в рамках субкультуры. Субкультуры, как правило, исчезают через несколько лет, как например, произошло с субкультурой хиппи или панков, и вместе с ними вымирает и их язык.

Многие исследователи полагают, что жаргон - это то, что присуще исключительно молодежи. Однако, на наш взгляд, все люди, являясь языковыми личностями, используют какой-то сленг - подростки, взрослые, богатые и бедные, профессионалы и безработные. Существует множество факторов, которые влияют на нашу речь. Это может быть возраст, пол, социальное положение, образование, национальность, место проживания или обучения, музыкальные, спортивные или телевизионные предпочтения и многое другое. Все эти факторы в совокупности влияют на речевое поведение и создают наш собственный язык, который является частью любой индивидуальности. Таким образом, сленг это субстандартная единица, которая обслуживает как отдельный языковой коллектив, так и конкретную отдельную личность, входящую в данный коллектив. 
Причины создания и употребления сленга зависят от индивидуальных особенностей. Типичной причиной создания сленга у подростков является стремление к кодированию речи. Они хотят отличаться от детей и взрослых, поэтому они создают свой собственный язык и используют его среди людей одного с ними возврата. Этот сленг используется в школе, в свободное время, с друзьями или во время интернет чатов и в социальных сетях. Помимо этого, они используют сленг, чтобы быть оригинальными и современными, забавными и не скучными, для того, чтобы привлечь внимание, избегать клише, быть ясными и краткими, чтобы смягчить или замаскировать заявление, повеселить публику, чтобы стать частью определенной школы, профессии, социального слоя или интеллектуальной группы и отграничиться от тех, кто не входит в эту группу.

Поскольку основными потребностями молодых людей являются потребность в самовыражении, самоидентификации, зашифрованности, а также в развлечении, ибо если людическая функция, как показал Хейзинга, свойственна человеку вообще [3] , то молодому человеку она свойственна тем более, мы можем заключить, что основными функциями молодежного сленга являются криптолалическая, людическая и репрезентативная. Язык молодежи, подверженный ультрабыстрому распространению и изменению, особенно благодаря средствам массовой информации, находится на стыке этих трёх функций.

Молодежный сленг - это одно из наиболее интересных явлений современной лингвистической науки, это живой организм, находящийся в процессе постоянного изменения и обновления. Его изучение, как функционального стиля позволяет заключить, что жаргон, сленг или социолект это не вредный, паразитарный нарост, загрязняющий и губительный для общепринятого литературного языка, а необходимая и неотъемлемая часть языковой системы, которая находится в постоянном развитии. Он вызывает определенный научный интерес, поскольку в нем, все свойственные 
естественному языку процессы, происходят гораздо быстрее и решительнее, не ограниченные и не сдерживаемые давлением нормы.

\section{Литература:}

1. Кудинова Т.А. Языковой субстандарт: социолингвистические, лингвокультурологические и лингопрагматические аспекты интерпретации //Автореф.дисс.канд.фил.наук. Нальчик, 2001. - 44 с.

2. Хейзинга Й. Homo ludens. В тени завтрашнего дня. М., 1992.- 61-62, 92 